\title{
Environmental effects on the recruitment variability of nursery species
}

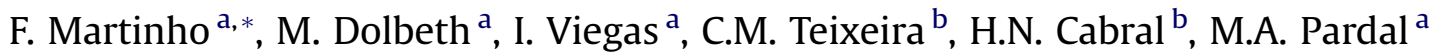 \\ ${ }^{a}$ Institute of Marine Research (IMAR), c/o Department of Zoology, Faculty of Science and Technology, University of Coimbra, $3004-517$ Coimbra, Portugal \\ ${ }^{\mathrm{b}}$ Centro de Oceanografia, Faculdade de Ciências da Universidade de Lisboa, Campo Grande, 1749-016 Lisboa, Portugal
}

\section{A R T I C L E I N F O}

\section{Article history:}

Received 30 December 2008

Accepted 20 April 2009

Available online 3 May 2009

\section{Keywords:}

recruitment variability

river runoff

hydrodynamics

NAO

flatfish

sea bass

\begin{abstract}
A B S T R A C T
The recruitment variability of the marine fish species Dicentrarchus labrax, Platichthys flesus and Solea solea was evaluated in the Mondego estuary (Portugal) from 2003 to 2007. The relationships between sea surface temperature, NAO index, coastal wind speed and direction, precipitation and river runoff prior to the estuarine colonization and the abundance of 0-group fish were evaluated using gamma-based Generalized Linear Models. Dicentrarchus labrax and P. flesus 0-group decreased in abundance towards the end of the study period, while S. solea, despite low abundance in 2004, increased in abundance in 2007. For D. labrax, river runoff, precipitation and east-west wind were significant; for P. flesus, precipitation, river runoff and both north-south and east-west wind components were significant parameters, while for $S$. solea only river runoff was important. Results were compared with recent projections for climate change scenarios, to evaluate their effects on future recruitment levels.
\end{abstract}

(c) 2009 Elsevier Ltd. All rights reserved.

\section{Introduction}

Estuaries are regarded as highly important sites for fish, particularly as nursery areas for marine species (Beck et al., 2001; McLusky and Elliott, 2004). In general, spawning takes place offshore, implying the migration of larvae from the continental shelf towards coastal areas and estuaries (e.g. Norcross and Shaw, 1984; Koutsikopoulos and Lacroix, 1992). Among other factors, hydrodynamics is a key factor for the recruitment success of marine fishes (van der Veer et al., 2000; Wilson et al., 2008); given the natural variability in current speeds and direction, the potential for drift into nursery environments of varying quality might be expected to result in high recruitment variability (Bailey et al., 2005).

Larval dispersion in early stages has several advantages, such as the potential for dispersion and colonization of new habitats, gene flow and minimization of intra-specific competition. Nonetheless, there are evident risks in dispersion towards estuarine waters, one of which is the high variability in recruitment strength. This problem is acute for marine fishes whose planktonic stages have high mortality rates (commonly measured at 5-40\% per day) and whose larval stages may metamorphose into quite different juvenile forms (Bailey et al., 2008). Among other species, many flatfish have their major spawning period in winter-early spring, when

\footnotetext{
* Corresponding author.

E-mail address: fmdm@ci.uc.pt (F. Martinho).
}

strong storm-related winds predominate, so there could be adaptations to wind-induced circulation (Marchand, 1991; Bailey et al., 2005). In the case of many estuarine-dependent species whose juvenile nursery habitats are spatially distinct from spawning locations, physical processes affecting the transport during the pelagic stages are of great importance to year-class strength (Amara et al., 2000; Bailey et al., 2005). Recruitment success in marine species seems to be regulated mostly by density-independent factors (van der Veer et al., 2000) related with the surrounding environment and climate, but also by density-dependent mechanisms such as predation, feeding and mortality. The strongest evidence of density-dependent regulation of recruitment in temperate flatfishes, both coastal and offshore, is the strong and direct relationship between the size of the nursery area and the output of juveniles (level of recruitment) (Rijnsdorp et al., 1992; van der Veer et al., 2000).

It is generally agreed that river plumes may have a crucial role as indicators of the proximity of nursery areas for fish larvae (e.g. Marchand, 1991; Amara et al., 2000). This means that in years of high river drainage these plumes extend over a greater area, increasing the probability of being detected by fish larvae spawned in the coast that will then direct their movement towards the nursery grounds (Vinagre et al., 2007). In agreement, Martinho et al. (2007a) reported higher abundance of estuarine residents and marine species that use estuaries as nursery grounds in years with higher freshwater flow. Changes in precipitation and river runoff regimes (due to climate change) will significantly impact on coastal ecosystems, and particularly on marine fish species whose larval 
stages depend on finding estuarine waters. In addition, large oceanic patterns such as the North Atlantic Oscillation (NAO) have been correlated with a range of long-term ecological measures, including the abundance of certain fish. Such environmental influences are most likely to affect susceptible juveniles during estuarine residence (Attrill and Power, 2002), thus having a potentially influential role in determining stock recruitment levels. Accordingly, variations in the NAO index were linked to different precipitation scenarios over the Portuguese territory (Zhang et al., 1997), being a potential indicator of changes in climate patterns over the years.

Previous work conducted in the Mondego estuary (Portugal, Southern Europe) (Leitão et al., 2007; Martinho et al., 2007a,b, 2008; Dolbeth et al., 2008) reported that this estuary acts as an important nursery ground for marine species such as the European sea bass Dicentrarchus labrax, flounder Platichthys flesus and sole Solea solea. In fact, these are among the most abundant species of the fish community (Martinho et al., 2007a). Understanding the combined effects of both large-scale oceanic and hydrological patterns with local specific pressures is thus crucial to the estimation of recruitment levels and ultimately, to the stock assessment for coastal fisheries. The objectives of this work were to assess the influence of the NAO, coastal wind speed and direction, sea surface temperature (SST), precipitation and river runoff on the recruitment variability of three marine species that use estuaries as nursery areas: $D$. labrax, $P$. flesus and $S$. solea and to evaluate the impact of future climate change scenarios on the recruitment of these species.

\section{Materials and methods}

\subsection{Study site}

The Mondego River estuary is a small intertidal system, located in the western Atlantic coast of Portugal $\left(40^{\circ} 08^{\prime} \mathrm{N}, 8^{\circ} 50^{\prime} \mathrm{W}\right)$ (Fig. 1). Its terminal part is divided into two arms (north and south) that join again near the mouth. The north arm is deeper, with $5-10 \mathrm{~m}$ depth at high tide and tidal range of $2-3 \mathrm{~m}$, while the south arm is shallower, with 2-4 $\mathrm{m}$ depth at high tide and tidal range of 1-3 m. The south arm is quite silted up in the upstream areas, which causes the freshwater to flow mainly by the north arm. In the south arm, about $75 \%$ of the total area consists of intertidal mudflats, while in the north arm they account for less than $10 \%$. The water circulation in the south arm is mainly dependent on the tides and on a small freshwater input, carried out through the Pranto River, a small tributary system, which is regulated by a sluice according to the water needs in the surrounding rice fields.

The Atlantic coast of the Iberian Peninsula is dominated in the summer months by equator-ward winds that generally start in late May or early June and persist through until late September or early October (Smyth et al., 2001). These winds cause an equator-ward mean surface flow to form above the predominantly pole-ward slope current and hence to generate coastal upwelling, inducing Ekman transport of the surface water away from the coast (Huthnance, 1995; Smyth et al., 2001; Mason et al., 2005). During the winter, winds change between northerly and southerly components, favourable of both upwelling and downwelling events, respectively (e.g. Santos et al., 2004). Local features of the northwest coast of Portugal include the Western Iberia Buoyant Plume (WIBP), a low salinity surface water fed by the winter-intensified runoff of several rivers (Santos et al., 2004), and the Iberian Pole ward Current (IPC), a weak undercurrent that often extends to the surface in the winter (Peliz et al., 2003).

\subsection{Sampling strategies and data acquisition}

Fish were collected from June 2003 to July 2007, in the following regime: from June 2003 to November 2006 on a monthly basis, and from January 2007 to July 2007, every two months. Sampling was carried out at five selected stations (M, N1, N2, S1 and S2) (Fig. 1b) at night, using a $2 \mathrm{~m}$ beam trawl, with one tickler chain and $5 \mathrm{~mm}$ mesh-size in the cod end. At each station, three tows of about $5 \mathrm{~min}$ were carried out, covering at least an area of $500 \mathrm{~m}^{2}$. All fish caught were immediately frozen, and in the lab were identified and counted.

Hydrological data were obtained from the INAG - Instituto da Água (http://snirh.inag.pt): monthly precipitation (from 2003 to 2007) was obtained from the Soure $13 F / 01 G$ station (near the estuary), and freshwater runoff was acquired from INAG station Açude Ponte Coimbra 12G/01A, near the city of Coimbra (located $40 \mathrm{~km}$ upstream) (see Fig. 1a). North Atlantic Oscillation (NAO) index (given by the pressure differences between Lisbon (Portugal) and Reykjavik (Iceland)) data were supplied by NOAA/National Weather Service - Climate Prediction Centre (http://www.cdc. noaa.gov). Sea surface temperature (SST), wind data, both northsouth and east-west components, were acquired from the International Comprehensive Ocean-Atmosphere Data Set (ICOADS) online database (http://dss.ucar.edu/pub/coads, Slutz et al., 1985) concerning the $1^{\circ}$ Lat $\times 1^{\circ}$ Long square nearest to the Mondego estuary.
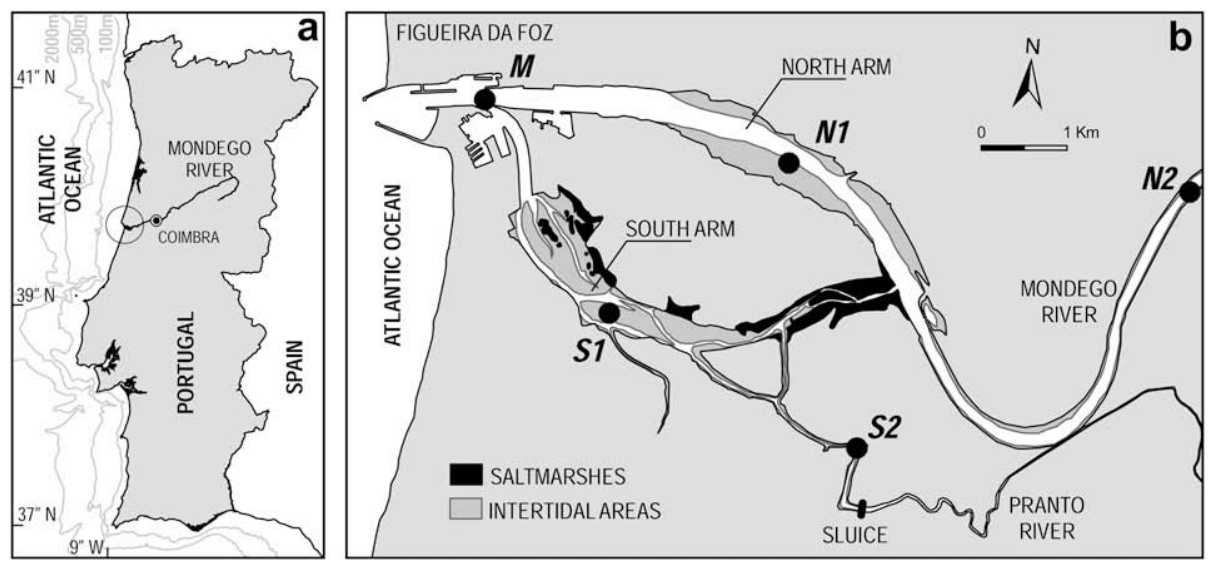

Fig. 1. Geographical location of the Mondego estuary in the Portuguese coast (a) and of the five sampling stations within the estuary (b). 


\subsection{Data analysis}

Data on abundance of 0-group juveniles were plotted from the original trawl data matrix according to Dolbeth et al. (2008) and Martinho et al. (2008) who determined that only one cohort is produced each year. Fish abundance (individuals per $1000 \mathrm{~m}^{2}$ ) was determined as the number of 0-group fish caught in the total sampled area. Monthly data were calculated as the average of all abundance from the five sampling stations for each species. From each yearly cohort, the abundance of the first three months when estuarine catches start were chosen, since they represented the onset of the 0-group settlement period; at this time, fish are approximately three months old. In general, Solea solea's recruitment to estuarine waters starts in the winter, whereas for Platichthys flesus and Dicentrarchus labrax the recruitment usually starts in early and late spring, respectively (Dolbeth et al., 2008; Martinho et al., 2008). The environmental parameters were obtained on the third month prior to the first estuarine catch, based on their expected influence on the colonization process.

The inter-annual relationship between the abundance of the three species and the environmental patterns (predictors) was analyzed with a Generalized Linear Model (GLM) in R software ( $R$ Development Core Team, 2008), where the number of fish is related to other measured variables through distributional assumptions (Stefánsson, 1996). A gamma distribution (only positive abundance) was used to model the non-zero catches (Myers and Pepin, 1990; Stefánsson, 1996). The GLM was built with an additive methodology: predictors were tested independently for significance and subsequently, significant predictors were added to determine the residual deviance, the percentage explained by each predictor and the total percentage of the deviance explained by the model. The final model was fitted only with the significant variables. Given that the considered species have different characteristics in terms of spawning, larval development and recruitment patterns, GLM analyses were performed separately for each species. A significance level of 0.05 was considered in all test procedures.

\section{Results}

\subsection{Environmental background}

Throughout the study period, both precipitation and river runoff had clear seasonal and yearly variations (Fig. 2). During 2004 and 2005 an extreme drought was recorded, with precipitation and river runoff values much lower than the 1961-1990 average (Fig. 2). The harshest effects of the drought were experienced in 2005. In 2003, 2006 and 2007, precipitation levels were comparable among years and to the 1961-1990 average (Fig. 2), being considered regular years. River runoff levels over the third month prior to the estuarine colonization by 0 -group juveniles presented high values in 2003 and 2004 for Dicentrarchus labrax, in 2003, 2004 and 2006 for Platichthys flesus and in 2003, 2006 and 2007 for Solea solea (Table 1). Over the same period, precipitation levels ranged from $35.90 \mathrm{~mm}$ to $80.90 \mathrm{~mm}$ for D. labrax, from $45.30 \mathrm{~mm}$ to $80.90 \mathrm{~mm}$ for P. flesus and from $0.00 \mathrm{~mm}$ to $257.00 \mathrm{~mm}$ for $S$. solea.

Sea surface temperature (SST) ranged from $13.74{ }^{\circ} \mathrm{C}$ to $15.57^{\circ} \mathrm{C}$ for Dicentrarchus labrax, with the lowest values in 2005 and 2006 (Table 1). For Platichthys flesus, SST varied from $14.15^{\circ} \mathrm{C}$ to $15.57^{\circ} \mathrm{C}$, with the lowest values in 2003, and for Solea solea higher SST values were recorded, ranging from $14.15^{\circ} \mathrm{C}$ to $19.59{ }^{\circ} \mathrm{C}$. As a general trend, SST over the third month prior to the estuarine colonization increased towards the end of the study period. NAO index in the third month prior to 0-group first appearance in the estuary (Table 1) ranged from -1.83 to 1.02 for $D$. labrax, being negative in 2005 and 2006, and positive in the remaining years. For P. flesus, the NAO index had negative values in 2004 and 2005, and positive values in 2003, 2006 and 2007, ranging from -0.30 to 1.26 . For S. solea, the NAO index was positive in 2003 and 2006, being negative in 2004, 2005 and 2007, varying from -2.24 to 1.26 .

Concerning the upwelling favourable winds (north-south component; negative values for northerly winds) (Table 1), for Platichthys flesus there was a clear increase in intensity along the study period from $-1.55 \mathrm{~m} \mathrm{~s}^{-1}$ to $-6.00 \mathrm{~m} \mathrm{~s}^{-1}$. For Dicentrarchus labrax, positive winds were only registered in 2005, varying from $-6.00 \mathrm{~m} \mathrm{~s}^{-1}$ to $2.95 \mathrm{~m} \mathrm{~s}^{-1}$, and for Solea solea, southerly winds only occurred in 2007, ranging from $-5.36 \mathrm{~m} \mathrm{~s}^{-1}$ to $3.51 \mathrm{~m} \mathrm{~s}^{-1}$. For all species, there was an increase in north-south wind intensity towards the end of the study period. East-west wind component (Table 1) (negative values for easterly winds) had in general lower and positive values for all species, evidencing an increase in intensity towards the end of the study period. The only negative values were recorded in 2006 for $P$. flesus and S. solea.

\subsection{Yearly variations in 0-group fish abundance}

Abundance of 0-group fish was highly variable between 2003 and 2007, with the highest abundance for the three species being reported in 2003 (Fig. 3). Dicentrarchus labrax was the species whose highest average yearly abundance was recorded (19.1 Ind. $1000 \mathrm{~m}^{-2}$ in 2003) (Fig. 3a). From 2004 onwards, abundance decreased considerably, with a minimum of 1.0 Ind. $1000 \mathrm{~m}^{-2}$ in 2007. A similar tendency was reported for Platichthys flesus, with the highest average yearly abundance in $2003\left(2.8 \mathrm{Ind} .1000 \mathrm{~m}^{-2}\right)$ and the lowest in 2006 (0.3 Ind. $1000 \mathrm{~m}^{-2}$ ) (Fig. 3b). Solea solea 0-group fish evidenced a distinct pattern: average yearly abundance in 2003 was higher ( 2.8 Ind. $1000 \mathrm{~m}^{-2}$ ), but the lowest values were achieved

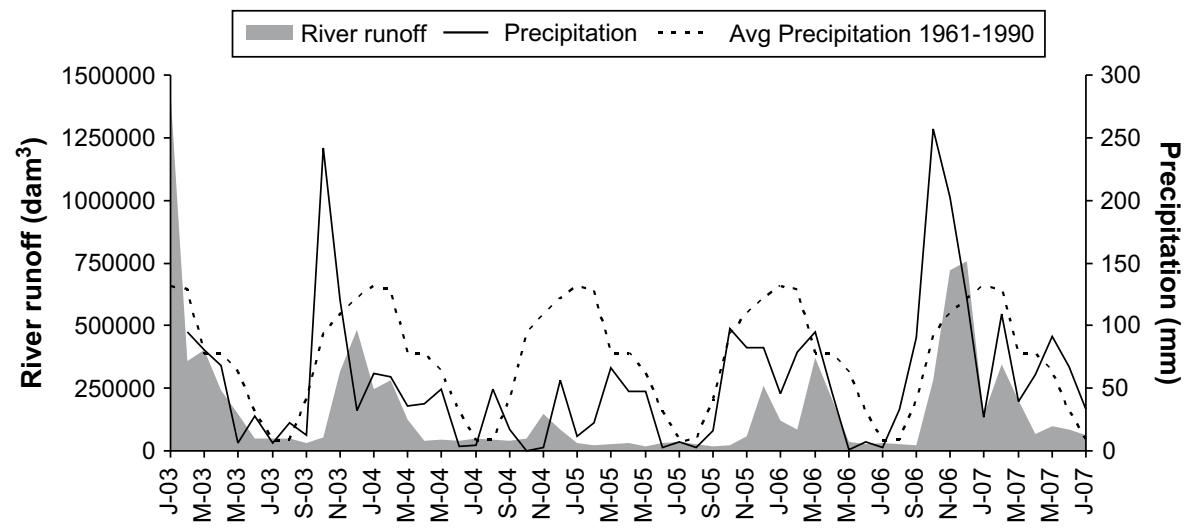

Fig. 2. Monthly variation of precipitation (mm), long-term average precipitation (1961-1990) (mm) and river runoff (dam ${ }^{3}$ ) from 2003 to 2007 in the Mondego river basin. 
Table 1

Values of the environmental variables used in the gamma-based GLM analysis by year and species.

\begin{tabular}{|c|c|c|c|c|c|c|c|}
\hline Species & Year & SST $\left({ }^{\circ} \mathrm{C}\right)$ & River runoff $\left(\right.$ dam $\left.^{3}\right)$ & Precipitation (mm) & NAO index & Wind $\mathrm{N}-\mathrm{S}\left(\mathrm{m} \mathrm{s}^{-1}\right)$ & Wind $\mathrm{E}-\mathrm{W}\left(\mathrm{m} \mathrm{s}^{-1}\right)$ \\
\hline \multirow[t]{5}{*}{ D. labrax } & 2003 & 14.15 & 403410.00 & 80.90 & 0.32 & -1.55 & 0.00 \\
\hline & 2004 & 14.28 & 125055.00 & 35.90 & 1.02 & -3.50 & 0.89 \\
\hline & 2005 & 13.91 & 26931.00 & 66.70 & -1.83 & 2.95 & 0.00 \\
\hline & 2006 & 13.74 & 87139.00 & 78.40 & -0.51 & -1.65 & 4.65 \\
\hline & 2007 & 15.57 & 68402.00 & 61.30 & 0.17 & -6.00 & 1.22 \\
\hline \multirow[t]{5}{*}{ P. flesus } & 2003 & 14.15 & 403410.00 & 80.90 & 0.32 & -1.55 & 0.00 \\
\hline & 2004 & 14.46 & 248020.00 & 61.60 & -0.29 & -2.67 & 0.00 \\
\hline & 2005 & 14.68 & 29532.00 & 47.30 & -0.30 & -3.06 & 2.50 \\
\hline & 2006 & 14.52 & 120468.00 & 45.30 & 1.26 & -5.36 & -0.94 \\
\hline & 2007 & 15.57 & 68402.00 & 61.30 & 0.17 & -6.00 & 1.22 \\
\hline \multirow[t]{5}{*}{ S. solea } & 2003 & 14.15 & 403410.00 & 80.90 & 0.32 & -1.55 & 0.00 \\
\hline & 2004 & 18.64 & 53594.00 & 242.10 & -1.26 & 0.00 & 0.00 \\
\hline & 2005 & 18.17 & 51028.00 & 0.00 & -1.10 & -2.76 & 0.68 \\
\hline & 2006 & 14.52 & 120468.00 & 45.30 & 1.26 & -5.36 & -0.94 \\
\hline & 2007 & 19.59 & 284262.00 & 257.00 & -2.24 & 3.51 & 2.90 \\
\hline
\end{tabular}

a

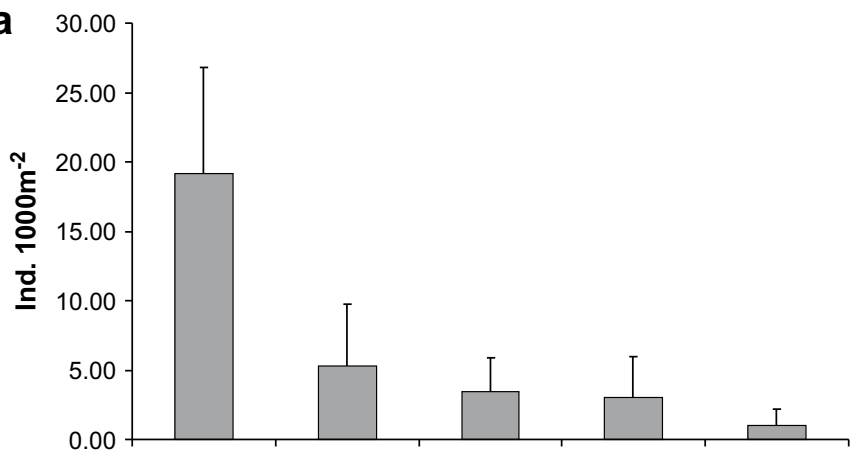

b

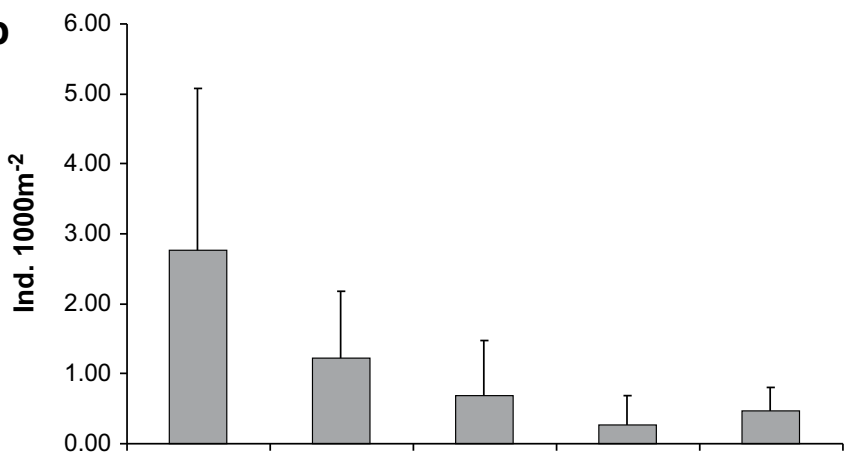

C

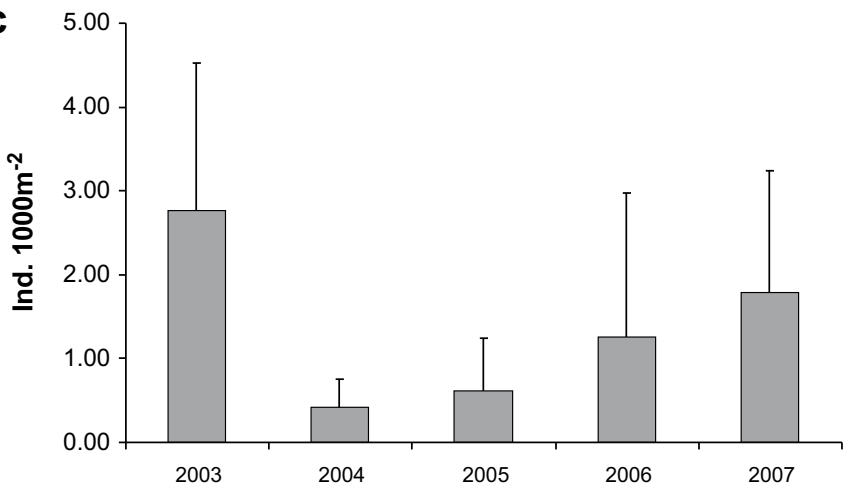

Fig. 3. Mean abundance ( \pm standard deviation) of (a) Dicentrarchus labrax, (b) Platichthys flesus and (c) Solea solea by year, from 2003 to 2007. in $2004\left(0.6\right.$ Ind. $1000 \mathrm{~m}^{-2}$ ), and from 2005 to 2007 there was a tendency to increase almost to 2003 levels (Fig. 3c).

Peak abundance for the three species was compared to the ones found in the most important Portuguese estuarine systems, according to the available literature, mainly from beam trawl surveys (Table 2). For Dicentrarchus labrax, peak abundance in the Mondego estuary was higher than in other estuaries, and for Platichthys flesus and Solea solea abundance was comparable across the range of selected estuarine systems, with the exception of the Minho estuary, where abundance was clearly higher.

\subsection{Relation between environmental parameters and 0-group abundance}

The final results of the Generalized Linear Models (GLMs) are reported in Table 3. The analysis of deviance for Dicentrarchus labrax showed that river runoff, precipitation and the east-west wind component were significant predictors explaining the 0 group abundance $(p<0.05)$. Besides the main effects, the firstorder interaction between river runoff and precipitation also was significant. The model explained $78.6 \%$ of the deviance, being river runoff mostly responsible for this (44.9\%) (See Table 3 ). The predictors precipitation and east-west wind component contributed similarly to the deviance ( $15.3 \%$ and $17.6 \%$, respectively), and the interaction between river runoff and precipitation contributed with $0.7 \%$. In general, there was a tendency for higher abundance of 0 -group $D$. labrax during the period of estuarine settlement in years of high river runoff and precipitation (Fig. $4 a$ and b), in accordance with the previous analysis. On the contrary, years with higher intensity of westerly winds were associated with lower abundance (Fig. 4c).

Analysis of deviance for Platichthys flesus indicated that river runoff, precipitation and both north-south and east-west wind components were significant predictors (Table 3 ). The model explained $74.9 \%$ of the deviance, with river runoff also being responsible for the majority of the deviance (73.7\%). The remaining predictors: precipitation, north-south and east-west wind components accounted for $1.2 \%$ of the deviance $(0.89 \%, 0.003 \%$ and $0.27 \%$, respectively). No significant first-order interactions were found between the main effects. Similar to Dicentrarchus labrax, $P$. flesus 0-group abundance was higher in years with higher river runoff and precipitation (Fig. 5a and b). Likewise, lower abundance was associated with higher intensity of westerly winds, and lower abundance was also associated with higher intensity of northerly winds (Fig. 5c, d). Regarding Solea solea, the model accounted for 
Table 2

Peak abundance reported for D. labrax, P. flesus and S. solea along the main estuarine systems of the Portuguese coast.

\begin{tabular}{|c|c|c|c|c|}
\hline Species & Location (estuary) & Max abundance (Ind. $1000 \mathrm{~m}^{-2}$ ) & Sampling gear & Reference \\
\hline D. labrax & $\begin{array}{l}\text { Ria de Aveiro } \\
\text { Mondego } \\
\text { Tejo } \\
\text { Guadiana }\end{array}$ & $\begin{array}{r}145.3 \\
320.0 \\
81.8 \\
10.0\end{array}$ & $\begin{array}{l}\text { Beach seine } \\
\text { Beam trawl } \\
\text { Beam trawl } \\
\text { Otter trawl }\end{array}$ & $\begin{array}{l}\text { Pombo et al. (2007) } \\
\text { Martinho et al. (2007b) } \\
\text { Cabral and Costa (2001) } \\
\text { Chícharo et al. (2006) }\end{array}$ \\
\hline P. flesus & $\begin{array}{l}\text { Minho } \\
\text { Douro } \\
\text { Ria de Aveiro } \\
\text { Mondego }\end{array}$ & $\begin{array}{r}236.0 \\
9.1 \\
23.2 \\
30.0\end{array}$ & $\begin{array}{l}\text { Beam trawl } \\
\text { Beam trawl } \\
\text { Beach seine } \\
\text { Beam trawl }\end{array}$ & $\begin{array}{l}\text { Cabral et al. (unpublished data) } \\
\text { Vinagre et al. (2005) } \\
\text { Pombo et al. (2007) } \\
\text { Martinho et al. (2007b) }\end{array}$ \\
\hline S. solea & $\begin{array}{l}\text { Minho } \\
\text { Douro } \\
\text { Ria de Aveiro } \\
\text { Mondego } \\
\text { Tejo } \\
\text { Sado } \\
\text { Mira }\end{array}$ & $\begin{array}{r}67.0 \\
8.0 \\
0.6 \\
23.1 \\
25.9 \\
24.5 \\
15.7\end{array}$ & $\begin{array}{l}\text { Beam trawl } \\
\text { Beam trawl } \\
\text { Beach seine } \\
\text { Beam trawl } \\
\text { Beam trawl } \\
\text { Beam trawl } \\
\text { Beam trawl }\end{array}$ & $\begin{array}{l}\text { Cabral et al. (unpublished data) } \\
\text { Vinagre et al. (2005) } \\
\text { Pombo et al. (2007) } \\
\text { Martinho et al. (2007b) } \\
\text { Cabral and Costa (1999) } \\
\text { Cabral (2000) } \\
\text { Cabral et al. (unpublished data) }\end{array}$ \\
\hline
\end{tabular}

$46.1 \%$ of the deviance (Table 3 ). From the set of chosen predictors, only river runoff was significant in the GLM analysis, being responsible for the whole deviance. Similarly to $P$. flesus, no firstorder interactions between the main effects were found. In accordance with the previous species, higher abundance of $S$. solea 0 -group fish was found in years with higher river runoff (Fig. 6).

\section{Discussion}

\subsection{Recruitment variability: role of environmental stressors}

The present work focuses on the influence of environmental aspects on the recruitment variability of marine fish species that use estuaries as nursery areas: Dicentrarchus labrax, Platichthys flesus and Solea solea. These species are among the most abundant marine fishes in Portuguese estuaries (e.g. Ribeiro et al., 2006;

Table 3

Analysis of deviance table for the gamma-based GLM fitted to the abundance data of the species considered in study. (Res. Dev. - residual deviance; \%Expl. - percentage of the deviance explained by the model).

\begin{tabular}{|c|c|c|c|c|c|}
\hline Species & Parameters & $p$-Value & Res. Dev. & Deviance & \%Expl. \\
\hline \multirow[t]{8}{*}{ D. labrax } & Null & & 31.772 & & \\
\hline & Main effects & & & & \\
\hline & Runoff & 0.0163 & 17.478 & 14.294 & 44.989 \\
\hline & Precipitation & 0.0003 & 12.628 & 19.144 & 15.265 \\
\hline & Wind E-W & 0.0109 & 7.035 & 24.737 & 17.604 \\
\hline & Interactions & & & & \\
\hline & Runoff: precipitation & 0.0034 & 6.799 & 24.973 & 0.742 \\
\hline & Total explained & & & & 78.600 \\
\hline \multirow[t]{7}{*}{ P. flesus } & Null & & 11.207 & & \\
\hline & Main effects & & & & \\
\hline & Runoff & 0.0006 & 2.944 & 8.263 & 73.729 \\
\hline & Precipitation & 0.0024 & 2.845 & 8.362 & 0.885 \\
\hline & Wind N-S & 0.0460 & 2.845 & 8.362 & 0.003 \\
\hline & Wind E-W & 0.0166 & 2.815 & 8.392 & 0.266 \\
\hline & Total explained & & & & 74.883 \\
\hline \multirow[t]{4}{*}{ S. solea } & Null & & 24.055 & & \\
\hline & Main effects & & & & \\
\hline & Runoff & 0.0093 & 12.977 & 11.078 & 46.053 \\
\hline & Total explained & & & & 46.053 \\
\hline
\end{tabular}

Cabral et al., 2007; Martinho et al., 2007a), with typical seasonal abundance peaks reflecting estuarine colonization by the young-ofthe-year. Since the present database concerns only five consecutive years, it was not possible to determine trends regarding recruitment variability and strength, since these species are known to have high variability in recruitment rates in consecutive years (Cabral and Costa, 2001).

Climate and its main features such as rain, SST, the NAO, wind speed and direction, as well as tidal movements and ocean currents, have been recognized as key issues in the estuarine colonization and settlement processes of both marine fish and invertebrate larvae (e.g. Marchand, 1991; Amara et al., 2000; Attrill and Power, 2002; Almeida and Queiroga, 2003; Bailey et al., 2008). One of the most significant aspects of this work was the identification of the importance of river runoff in this process for the three species in study. In fact, this was the only parameter that was significant for all species. Previous studies in the Tagus estuary (Portugal) revealed that river drainage is a determining factor in the estuarine colonization process undertaken by marine species, particularly for soles (Vinagre et al., 2007). In the Bay of Vilaine (France), Amara et al. (2000) pointed out that the initiation of sole estuarine colonization is regulated by a combination of river flow, wind direction and intensity and tidal cycle.

During the study period a severe drought occurred, leading to a significant decrease in precipitation and river runoff values. According to the present results, higher runoff values were associated with higher abundance of Dicentrarchus labrax, Platichthys flesus and Solea solea, as well as precipitation for D. labrax and P. flesus. River runoff not only affects the extent of river plumes into coastal areas, but can also be responsible for salinity changes within estuarine waters (one of the main factors responsible for the structuring of estuarine fish communities (e.g. Marshall and Elliott, 1998; Drake et al., 2002; Costa et al., 2007; Leitão et al., 2007), protracting or diminishing the available habitats for fish and suitable nursery areas. Effectively, Marques et al. (2007) and Martinho et al. (2007a) described a higher proportion of marine species in plankton and fish communities during low runoff periods, respectively, due to a higher extent of the salinity incursion inside estuarine waters. The importance of river plumes for the estuarine colonization of fish and invertebrate larvae has been related to the existence of chemical cues that orient larvae towards estuarine areas and settlement habitats, such as odour, temperature, salinity and turbidity (e.g. Miller, 1988; Gibson, 1997; Arvelund and Takemura, 2006; Krimsky and Epifânio, 2008) and to potential higher primary production (Costa et al., 2007). Also, in accordance with 

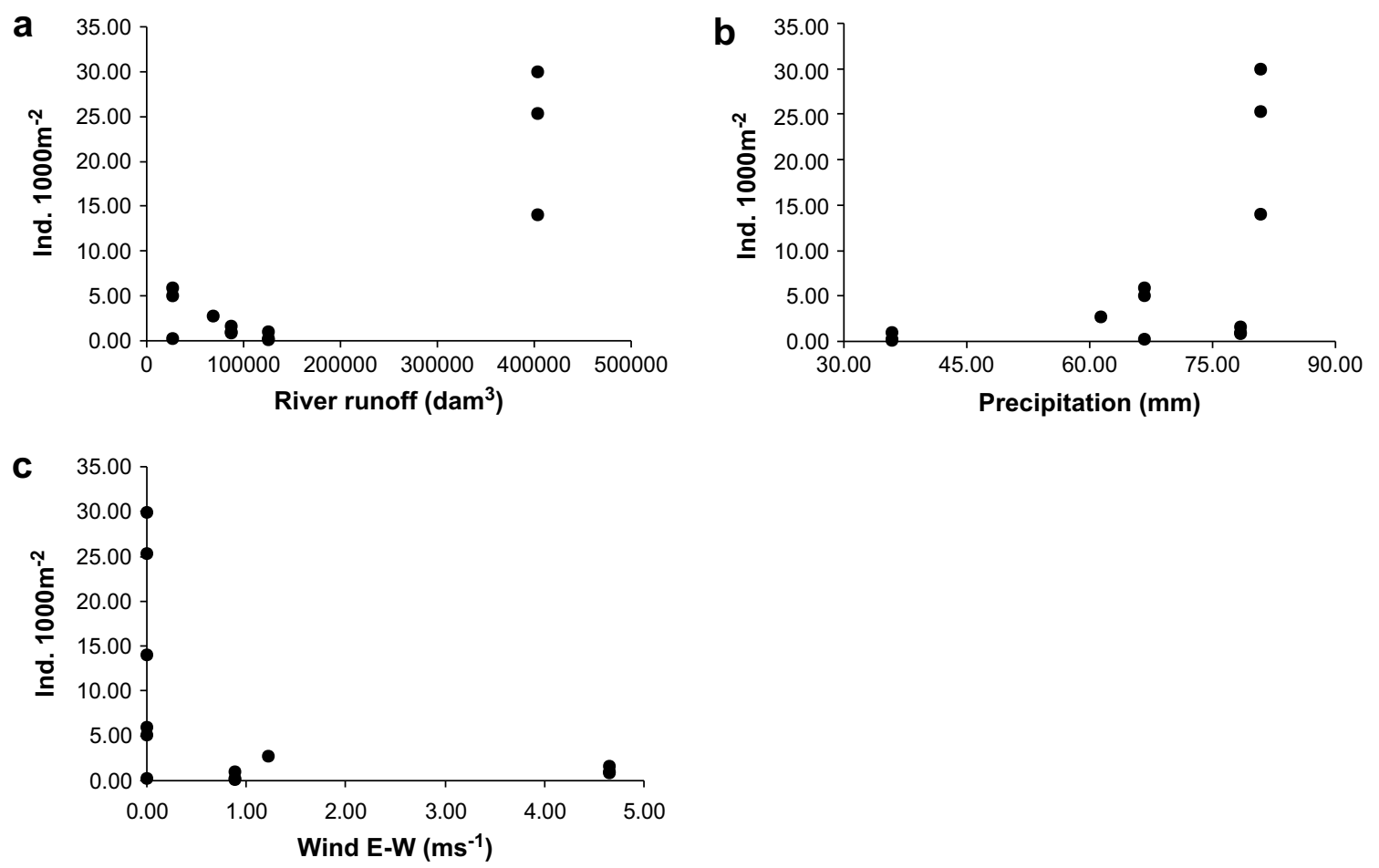

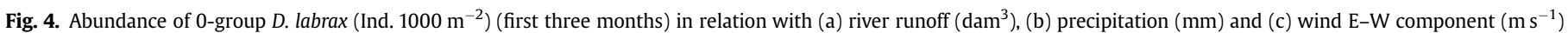
concerning the third month prior to the period of estuarine colonization.

Vinagre et al. (2007), a wider extent of river plumes during high freshwater flow will enhance the chance of larvae detecting and moving towards estuarine waters, which is in agreement with the present results. Regarding fisheries, Salen-Picard et al. (2002) identified a positive relationship between high runoff values and
S. solea landings after a 5-year time lag in the Golf of Lions (France, Mediterranean coast). The same authors pointed out that flooding events were responsible for an increase in benthic food resources for juvenile fish. Sentchev and Korotenko (2004) based on three dimension particle-tracking transport models, evidenced that tides
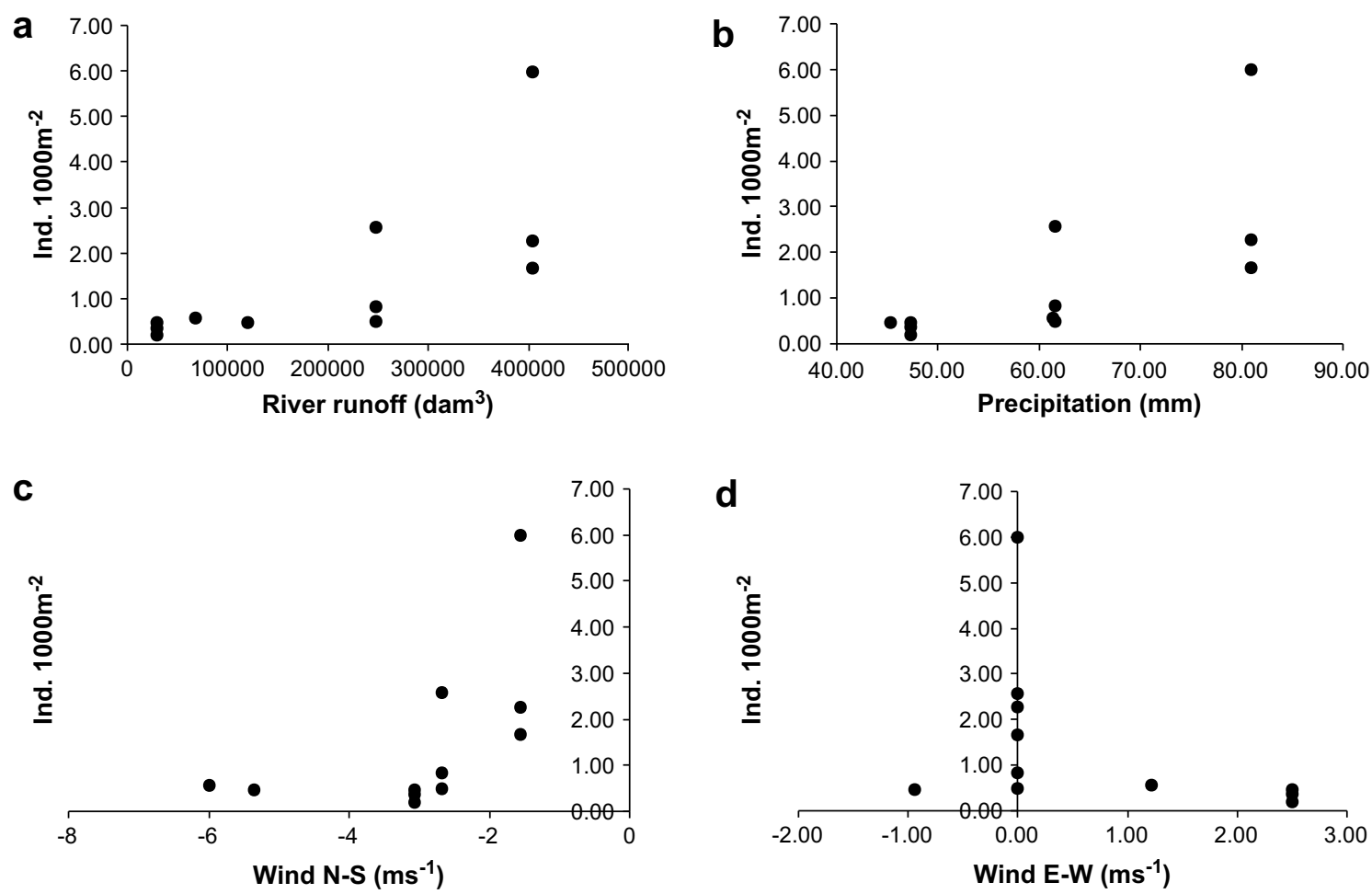

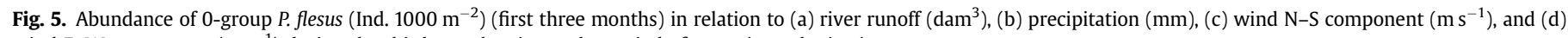
wind $\mathrm{E}-\mathrm{W}$ component $\left(\mathrm{m} \mathrm{s}^{-1}\right)$ during the third month prior to the period of estuarine colonization. 


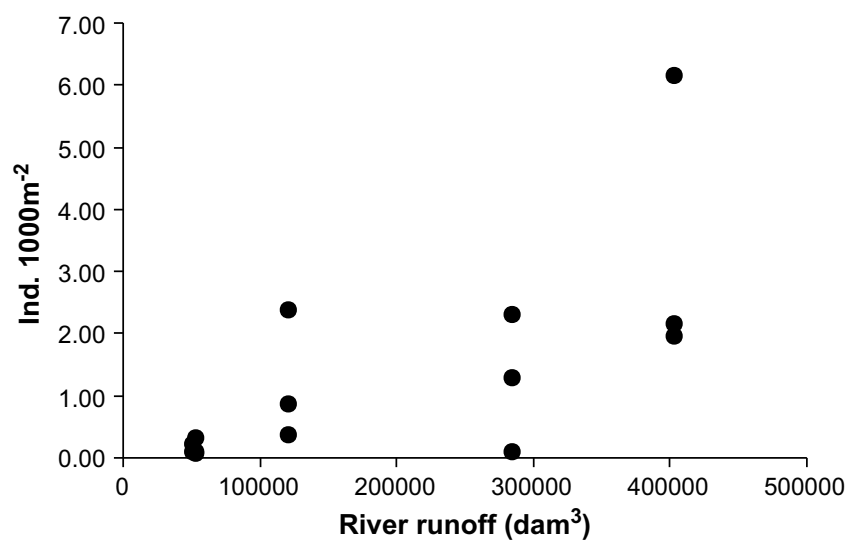

Fig. 6. Abundance of 0 -group S. solea (Ind. $1000 \mathrm{~m}^{-2}$ ) (first three months) in relation with river runoff $\left(\mathrm{dam}^{3}\right)$ during the third month prior to the period of estuarine colonization.

and freshwater discharge play a critical role in influencing flounder larval transport over the eastern English Channel, from spawning areas to nursery grounds. For the three studied species, the spawning season in temperate latitudes and estuarine colonization processes seem to have evolved to match the season when river plumes have their maximum extent, thus increasing the chance for recruitment success.

One important regulatory aspect in the estuarine colonization of larvae and young stages seems to be transportation from the continental shelf to estuarine nurseries, with several authors stressing the importance of wind-driven and tidal-driven circulations (e.g. Jennings and Pawson, 1992; Amara et al., 2000; Sentchev and Korotenko, 2004). In the present study, wind was determined as a significant predictor for Dicentrarchus labrax (E-W component) and for Platichthys flesus (N-S and E-W components). Nevertheless, for both wind components, the weakest intensities were associated with the highest abundance of 0 -group fish, possibly indicating that lower wind intensity induces either weaker upwelling events or turbulence. The present results are in accordance with prior results obtained by Amara et al. (2000), who pointed out that strong offshore winds can be unfavourable to the estuarine dispersion. For D. labrax, Lancaster et al. (1998) concluded that differences in recruitment levels could be attributed to variations in coastal wind direction and strength.

For several species, selective tidal stream transport (STST) has been proposed as the main process for larvae entering estuaries. For Platichthys flesus, passive transport occurs in their early life, followed by active STST (van der Veer et al., 1991), in which fishes make use of strong tidal currents over one part of the tidal cycle for transportation (Forward and Tankersley, 2001). In the Bay of Biscay (France), Lagardère et al. (1999) observed that Solea solea larvae were mainly located in the lower part of the water column before migration to estuaries. Vinagre et al. (2007) pointed out that soles undertake vertical movements to escape the top layer of water masses that are most susceptible to wind and offshore advection, important in upwelling systems such as the Portuguese coast. In opposition, field studies conducted in South Wales indicated that Dicentrarchus labrax larvae tended to occur in the upper part of the water column, and the arrival of post-larvae into sheltered bays and estuaries usually takes place during spring tides (Jennings and Pawson, 1992). These differences could be attributed to the different vertical guilds of $D$. labrax, a demersal and more active swimming species, and $P$. flesus and $S$. solea, both benthic species.

The dominance of density-independent factors operating at a local scale on the egg and larval stages stresses the importance of hydrodynamic circulation as a key factor in determining year-class strength (Leggett and Frank, 1997). Also, recruitment variability has been shown to depend on the pelagic stage duration (van der Veer et al., 2000), either before metamorphosis or during the juvenile period (Lagardère et al., 1999; Amara et al., 2000). Despite fish larvae having been described as active swimmers, Gibson (1997) stressed that during the estuarine colonization processes they are still under the influence of hydrodynamic forces and successful recruitment during this stage is mostly dependent upon favourable hydrographic conditions. Although density-independent factors have been shown to influence recruitment variability in the marine environment prior to estuarine colonization (e.g. Rijnsdorp et al., 1992), density-dependent factors may also have a high preponderance within nursery grounds, inducing high levels of juvenile mortality (Gibson, 1994; Rogers, 1994).

For the species in study there was no relationship between early juvenile abundance and sea surface temperature. However, according to Rijnsdorp et al. (1992), recruitment is likely to be mostly influenced by water temperature in the marine environment prior to or during the immigration to nursery areas. For Solea solea, Le Pape et al. (2003) found a positive relationship between SST and the growth of young recruits. The same authors also pointed out that warmer temperatures are an important factor for the attraction to estuarine nurseries. In opposition, for several flatfish species (dab and plaice), a negative relationship between year-class strength and water temperature has been determined (van der Veer et al., 2000). Regarding Dicentrarchus labrax, Jennings and Pawson (1992) pointed out that, in UK waters, post-larvae migrate to inshore waters when temperatures are higher than those of the surrounding sea.

The North Atlantic Oscillation (NAO) has been correlated with a range of long-term ecological measures, including fish stocks. Such environmental influences are most likely to affect susceptible juveniles during estuarine residency, as estuaries are critical juvenile nursery or over-wintering habitats (Attrill and Power, 2002). Nonetheless, none of the selected species revealed to have a significant influence by the NAO, which as a large-scale oceanographic process, influences not only the SST, but also the wind and current patterns along the Portuguese coast (Henriques et al., 2007). The main effects of the NAO on the recruitment and estuarine colonization of marine fish can be most likely observed at a broader scale, either in time or space, than the ones used in this study. Nevertheless, the isolation of single factors that can influence recruitment patterns can be somewhat difficult, since the movement from offshore waters to inshore protected areas is a complex and intricate process. In fact, it is likely that local- and meso-scale singularities in hydrography, bathymetry or landscape structure may also contribute to regional differences in transport processes (Bailey et al., 2008). In addition, and according to Mestres et al. (2007), the extension of river plumes, derived from the only predictor that was considered significant in the GLM analysis for the three species (river runoff), is clearly influenced by the main local driving mechanisms, namely the prevailing wind and the freshwater discharge rate, and even within a species, there may be local adaptations reflecting quite different strategies (Bailey et al., 2008).

\subsection{Dicentrarchus labrax, Platichthys flesus and Solea solea in Portuguese estuaries}

Regarding D. labrax, the highest abundance in Portuguese estuaries was recorded in the Mondego estuary. In a recent work by Vasconcelos et al. (2008), the authors identified by otolith elemental fingerprints that about $40 \%$ of the coastal stocks of this species were originated in the Mondego nurseries, thus reinforcing the role of the Mondego estuary for coastal stocks. For P. flesus, 
a decrease in abundance towards south is consistent with Cabral et al. (2001), who reported the decrease in abundance near its southern limit of distribution, located along the centre of the Portuguese Atlantic coast. The highest abundance was recorded in the Minho estuary (North Portuguese coast), and in agreement, Vasconcelos et al. (2008) indicated that at least half of this species' coastal stocks were originated in a northern estuary (Douro estuary). As for $S$. solea, nursery origins were determined to be mostly from the Mondego and Tagus estuaries, although with less reliability (Vasconcelos et al., 2008). This species seems to be the most ubiquitous in the Portuguese coast, with similar abundance found over the selected estuaries. However, the highest abundance was recorded at the Minho estuary, similarly to P. flesus. As a general trend, higher abundance was found in northern estuaries.

\subsection{Climate change scenarios: future perspectives in recruitment levels}

Recent climate change projections for the Iberian Peninsula point out that both temperature and drought periods are expected to increase, with a concentration of rainfall in the winter months (Miranda et al., 2006). More precisely, and based on the Intergovernmental Panel on Climate Change-Special Report on Emissions Scenarios (IPCC-SRES) (IPCC, 2001) models, winter precipitation by the end of the XXI century is predicted to decrease to an average 15\% (Miranda et al., 2006). According to the previous authors, reductions in precipitation amounts throughout the year are expected to be higher: $-20 \%$ to $-50 \%$. Considering this, the decrease in precipitation and consequently river runoff will lead to a reduction of the extent of river plumes to coastal waters, which has been determined as an important factor for the recruitment success of marine fish that use estuaries as nursery areas. As a significant outcome, runoff regime shifts can induce changes in coastal fisheries: Meynecke et al. (2006) based on a data series from 1988 to 2004, concluded that dry years were often associated with lower catches, leading to important economic and social losses. Due to the concentration of precipitation in time, restricted to the winter months, it is possible that species that migrate to estuaries in spring, such as Dicentrarchus labrax and Platichthys flesus, can be significantly impacted due to the decrease in runoff and to the lesser extent of river plumes, in agreement with the present results and with Vinagre et al. (2007). In fact, in the present study, these species showed a decrease in abundance during and after the drought, in opposition to Solea solea. In addition, previous work by Dolbeth et al. (2008) indicated a breakdown of secondary production in nursery species during the drought, which can be an indicator that continued decreases in river runoff can in fact impact on these species. Regarding this scenario, it is possible to infer that $D$. labrax and $P$. flesus will be more affected by drought events in the future, thus requiring efficient management measures.

Further improvements on this approach would be the integration of plankton and reproductive biology data in order to obtain a more accurate scenario of the estuarine colonization processes. In addition, extending this time-series would allow a better definition of the physical and environmental conditions that contribute to the recruitment variability in the studied species and that operate over larger time and spatial scales.

\section{Acknowledgements}

The authors would like to thank all colleagues who participated in field and laboratory work. This work was supported by Instituto de Investigação Interdisciplinar - Universidade de Coimbra, through a Ph.D grant attributed to (III/AMB/33/2005) and through a Research Project "Os recursos pesqueiros no âmbito da política europeia de desenvolvimento sustentável: uma abordagem interdisciplinar para o caso do robalo (Dicentrarchus labrax)" (III/AMB/4/ 2005). The two anonymous referees are also acknowledged for contributing to the final manuscript.

\section{References}

Almeida, M.J., Queiroga, H., 2003. Physical forcing of onshore transport of crab megalopae in the northern Portuguese upwelling system. Estuarine, Coastal and Shelf Science 57, 1091-1102.

Amara, R., Lagardère, F., Desaunay, Y., Marchand, J., 2000. Metamorphosis and estuarine colonization in the common sole, Solea solea (L.): implications for recruitment regulation. Oceanolica Acta 23, 469-484.

Arvelund, M., Takemura, A., 2006. The importance of chemical environmental cues for juvenile Lethrinus nebulosus Forsskål (Lethrinidae, Teleostei) when settling into their first benthic habitat. Journal of Experimental Marine Biology and Ecology 338, 112-122.

Attrill, M.J., Power, M., 2002. Climatic influence on a marine fish assemblage. Nature $417,275-278$

Bailey, K.M., Nakata, H., van der Veer, H.W., 2005. The planktonic stages of flatfishes: physical and biological interactions in transport processes. In: Gibson, R.N. (Ed.), Flatfishes, Biology and Exploitation. Blackwell Publishing, Oxford, pp. 94-119.

Bailey, K.M., Abookire, A.A., Duffy-Anderson, J.T., 2008. Ocean transport paths for the early life history stages of offshore-spawning flatfishes: a case study in the Gulf of Alaska. Fish and Fisheries 9, 44-66.

Beck, M.W., Heck Jr., K.L., Able, K.W., Childers, D.L., Eggleston, D.B., Gillanders, B.M., Halpern, B., Hays, C.G., Hoshino, K., Minello, T.J., Orth, R.J., Sheridan, P.F., Weinsetin, M.P. 2001. The identification, conservation, and management of estuarine and marine nurseries for fish and invertebrates. Bioscience 51,633-641.

Cabral, H.N., 2000. Distribution and abundance patterns of flatfishes in the Sado estuary, Portugal. Estuaries 23, 351-358.

Cabral, H.N., Costa, M.J., 1999. Differential use of the nursery areas within the Tagus estuary by sympatric soles, Solea solea and Solea senegalensis. Environmental Biology of Fishes 56, 389-397.

Cabral, H.N., Costa, M.J., 2001. Abundance, feeding ecology and growth of 0-group sea bass, Dicentrarchus labrax, within the nursery areas of the Tagus estuary. Journal of the Marine Biological Association of the UK 81, 679-682.

Cabral, H.N., Costa, M.J., Salgado, J.P., 2001. Does the Tagus estuary fish community reflect environmental changes? Climate Research 18, 119-126.

Cabral, H.N., Vasconcelos, R.P., Vinagre, C., França, S., Fonseca, V., Maia, A., ReisSantos, P., Lopes, M., Ruano, M., Campos, J., Freitas, V., Santos, P.T., Costa, M.J., 2007. Relative importance of estuarine flatfish nurseries along the Portuguese coast. Journal of Sea Research 57, 209-217.

Chícharo, M.A., Chícharo, L., Morais, P., 2006. Inter-annual differences of ichthyofauna structure of the Guadiana estuary and adjacent coastal area (SE Portugal/ SW Spain): before and after Alqueva dam construction. Estuarine, Coastal and Shelf Science 70, 39-51.

Costa, M.J., Vasconcelos, R., Costa, J.L., Cabral, H.N., 2007. River flow influence on the fish community of the Tagus estuary (Portugal). Hydrobiologia 587, 113-123.

Dolbeth, M., Martinho, F., Viegas, I., Cabral, H., Pardal, M.A., 2008. Estuarine production of resident and nursery fish species: conditioning by drought events? Estuarine, Coastal and Shelf Science 78, 51-60.

Drake, P., Árias, A.M., Baldo, F., Cuesta, J.A., Rodríguez, A., Sobrino, I., Silva-García, A., García-González, D., Fernández-Delgado, C., 2002. Spatial and temporal variation of the aquatic nekton and hyperbenthos from a temperate European estuary with a regulated freshwater inflow. Estuaries 25, 451-468.

Forward, R.B., Tankersley, R.A., 2001. Selective tidal-stream transport of marine animals. Oceanography and Marine Biology an Annual Review 39, 305-353.

Gibson, R.N., 1994. Impact of habitat quality and quantity on the recruitment of juvenile flatfishes. Netherlands Journal of Sea Research 32, 191-206.

Gibson, R.N., 1997. Behaviour and the distribution of flatfishes. Journal of Sea Research 37, 241-256.

Henriques, M., Gonçalves, E.J., Almada, V.C., 2007. Rapid shifts in a marine fish assemblage follow fluctuations in winter sea conditions. Marine Ecology Progress Series 340, 259-270.

Huthnance, J.M., 1995. Circulation, exchange and water masses at the ocean margin: the role of physical processes at the shelf edge. Progress in Oceanography 35, 353-431.

IPCC, 2001. Summary for policymakers: climate change 2001: impacts, adaptation and vulnerability. In: McCarthy, J.J., Cauziani, O.F., Leary, N.A., Dokken, D.J., White, K.S. (Eds.), Climate Change 2001: Impacts, Adaption, and Vulnerability: Contribution of Working Group II to the Third Assessment Report of the Intergovernmental Panel on Climate Change. Intergovernmental Panel on Climate Change, Cambridge University Press, Cambridge, 913 pp.

Jennings, S., Pawson, M.G., 1992. The origin and recruitment of bass, Dicentrarchus labrax, larvae to nursery areas. Journal of the Marine Biological Association of the UK 72, 199-212.

Koutsikopoulos, C., Lacroix, N., 1992. Distribution and abundance sole (Solea solea (L.)) eggs and larvae in the Bay of between 1986 and 1989. Netherlands Journal of Sea Research 29, 81-91.

Krimsky, L.S., Epifânio, C.E., 2008. Multiple cues from multiple habitats: effect on metamorphosis of the Florida stone crab, Menippe mercenaria. Journal of Experimental Marine Biology and Ecology 358, 178-184. 
Lancaster, J.E., Pawson, M.G., Pickett, G.D., Jennings, S., 1998. The impact of the 'Sea Empress' oil spill on sea bass recruitment. Marine Pollution Bulletin 9, 677-688.

Lagardère, F., Amara, R., Joassarda, L., 1999. Vertical distribution and feeding activity of metamorphosing sole, Solea solea, before immigration to the Bay of Vilaine nursery (northern Bay of Biscay, France). Environmental Biology of Fishes 56, 213-228.

Leggett, W.C., Frank, K.T., 1997. A comparative analysis of recruitment variability in North Atlantic flatfishes - testing the species range hypothesis. Journal of Sea Research 37, 281-299.

Leitão, R., Martinho, F., Cabral, H., Jorge, I., Marques, J.C., Pardal, M.A., 2007. The fish assemblage of the Mondego estuary: composition, structure and trends over the past two decades. Hydrobiologia 587, 269-279.

Le Pape, O., Holley, J., Guérault, D., Désaunay, Y., 2003. Quality of coastal and estuarine essential fish habitats: estimations based on the size of juvenile common sole (Solea solea L.). Estuarine, Coastal and Shelf Science 58, 793-803.

Marchand, J., 1991. The influence of environmental conditions on settlement, distribution and growth of 0 -group sole (Solea solea (L.)) in a macrotidal estuary (Vilaine, France). Netherlands Journal of Sea Research 27, 307-316.

Marques, S.C., Azeiteiro, U.M., Martinho, F., Pardal, M.A., 2007. Climate variability and planktonic communities: the effect of an extreme event (severe drought) in a southern European estuary. Estuarine, Coastal and Shelf Science 73, 725-734.

Martinho, F. Leitão, R., Viegas, I., Neto, J.M., Dolbeth, M., Cabral, H.N., Pardal, M.A 2007a. The influence of an extreme drought event in the fish community of a southern Europe temperate estuary. Estuarine, Coastal and Shelf Science 75, 537-546.

Martinho, F., Leitão, R., Neto, J.M., Cabral, N.H., Marques, J.C., Pardal, M.A., 2007b. The use of nursery areas by juvenile fish in a temperate estuary, Portugal. Hydrobiologia 587, 281-290.

Martinho, F., Leitão, R., Neto, J.M., Cabral, H., Lagardère, F., Pardal, M.A., 2008 Estuarine colonization, population structure and nursery functioning for 0 group sea bass (Dicentrarchus labrax), flounder (Platichthys flesus) and sole (Solea solea) in a mesotidal temperate estuary. Journal of Applied Ichthyology 24, 229-237.

Marshall, S., Elliott, M., 1998. Environmental influences on the fish assemblage of the Humber Estuary, United Kingdom. Estuarine, Coastal and Shelf Science 46, 175-184.

Mason, E., Santos, A.M.P., Peliz, A.J., 2005. Western Iberian winter wind indices based on significant wind events. Ocean Science Discusssions 2, 105-127.

McLusky, D.S., Elliott, M., 2004. The Estuarine Ecosystem: Ecology, Threats and Management, third ed. Oxford University Press, Oxford, $214 \mathrm{pp}$.

Mestres, M., Sierra, J.P., Sánchez-Arcilla, A., 2007. Factors influencing the spreading of a low-discharge river plume. Continental Shelf Research 27, 2116-2134.

Meynecke, J.O., Lee, S.Y., Duke, N.C., Warken, J., 2006. Effect of rainfall as a component of climate change on estuarine fish production in Queensland, Australia. Estuarine, Coastal and Shelf Science 69, 491-504.

Miller, J., 1988. Physical processes and the mechanisms of coastal migrations of immature marine fishes. American Fisheries Society Symposium 3, 68-76.

Miranda, P.M.A., Valente, M.A., Tomé, A.R., Trigo, R., Coelho, F.E.S., Aguiar, A., Azevedo, E.B., 2006. O Clima de Portugal nos séculos XX e XXI. In: Santos, F.D., Miranda, P. (Eds.), Alterações climáticas em Portugal, cenários, impactos e medidas de adaptação - SIAM II Project. Gradiva, Lisboa, pp. 47-113. Available from: http://www.siam.fc.ul.pt/siam.html.

Myers, R.A., Pepin, P., 1990. The robustness of lognormal based estimators of abundance. Biometrics 46, 1185-1192.

Norcross, B.L., Shaw, R.F., 1984. Oceanic and estuarine transport of fish eggs and larvae: a review. Transactions of the American Fisheries Society 113, 153-165.
Peliz, A., Dubert, J., Haidvogel, D.B., Le Cann, B., 2003. Generation and unstable evolution of a abundance-driven Eastern Pole ward current: the Iberia pole ward current. Journal of Geophysical Research 108 (C8), 3268.

Pombo, L., Rebelo, J.E., Elliott, M., 2007. The structure, diversity and somatic production of the fish community in an estuarine coastal lagoon, Ria de Aveiro (Portugal). Hydrobiologia 587, 253-268.

R Development Core Team, 2008. R: A Language and Environment for Statistica Computing. R Foundation for Statistical Computing, Vienna, Austria, ISBN 3 900051-07-0.

Ribeiro, J., Bentes, L., Coelho, R., Gonçalves, J.M.S., Lino, P.G., Monteiro, P., Erzini, K. 2006. Seasonal, tidal and diurnal changes in fish assemblages in the Ria Formosa lagoon (Portugal). Estuarine, Coastal and Shelf Science 67, 461-474.

Rijnsdorp, A.D., van Beek, F.A., Flatman, S., Millner, R.N., Riley, J.D., Giret, M., De Clerck, R., 1992. Recruitment of sole stocks, Solea solea (L.), in the northeast Atlantic. Netherlands Journal of Sea Research 29, 173-192.

Rogers, S.I., 1994. Population abundance and growth rate of juvenile sole Solea solea (L.). Netherlands Journal of Sea Research 32, 353-360.

Salen-Picard, C., Darnaude, A.M., Arlhac, D., Harmelin-Vivien, M.L., 2002. Fluctuations of macrobenthic populations: a link between climate-driven river run-off and sole fishery yields in the Gulf of Lions. Oecologia 133, 380-388.

Santos, A.M.P., Peliz, A.J., Dubert, J., Oliveira, P.B., Angélico, M.M., Ré, P., 2004. Impact of a winter upwelling event on the distribution and transport of sardine (Sardina pilchardus) eggs and larvae off western Iberia: a retention mechanism. Continental Shelf Research 24,149-165.

Sentchev, A., Korotenko, K., 2004. Stratification and tidal current effects on larva transport in the Eastern English Channel: observations and 3D modeling. Environmental Fluid Mechanics 4, 305-331.

Slutz, R.J., Lubker, S.J., Hiscox, J.D., Woodruff, S.D., Jenne, R.L., Joseph, D.H., Steuer, P.M., Elms, J.D., 1985. Comprehensive Ocean-Atmosphere Data Set: Release 1 Number, $268 \mathrm{pp}$

Smyth, T.J., Miller, P.I., Groom, S.B., Lavender, S.J., 2001. Remote sensing of sea surface temperature and chlorophyll during Lagrangian experiments at the Iberian margin. Progress in Oceanography 51, 269-281.

Stefánsson, G., 1996. Analysis of groundfish survey abundance data: combining the GLM and delta approaches. ICES Journal of Marine Science 53, 577-588.

van der Veer, H.W., Bergman, M.J.N., Dapper, R., Witte, J.I.J., 1991. Population dynamics of an intertidal 0-group flounder Platichthys flesus population in the western Dutch Wadden Sea. Marine Ecology Progress Series 73, 141-148.

van der Veer, H.W., Berghahn, R., Miller, J.M., Rijnsdorp, A.D., 2000. Recruitment in flatfish, with special emphasis on North Atlantic species: progress made by the Flatfish Symposia. ICES Journal of Marine Science 57, 202-215.

Vasconcelos, R.P., Reis-Santos, P., Tanner, S., Maia, A., Latkoczy, C., Günther, D. Costa, M.J., Cabral, H., 2008. Evidence of estuarine nursery origin of five coastal fish species along the Portuguese coast through otolith elemental fingerprints. Estuarine, Coastal and Shelf Science 79, 317-327.

Vinagre, C., França, S., Costa, M.J., Cabral, H.N., 2005. Niche overlap between juvenile flatfishes, Platichthys flesus and Solea solea, in a southern European estuary and adjacent coastal waters. Journal of Applied Ichthyology 21, 114-120.

Vinagre, C., Costa, M.J., Cabral, H.N., 2007. Impact of climate and hydrodynamics on sole larval immigration towards the Tagus estuary, Portugal. Estuarine, Coastal and Shelf Science 75 (4), 516-524.

Wilson, J.R., Broitman, B.R., Caselle, J.E., Wendt, D.E., 2008. Recruitment of coastal fishes and oceanographic vaiability in central California. Estuarine, Coastal and Shelf Science 79, 483-490.

Zhang, X., Wang, X.L., Corte-Real, J., 1997. On the relationships between daily circulation patterns and precipitation in Portugal. Journal of Geophysical Research 102, 13495-13507. 